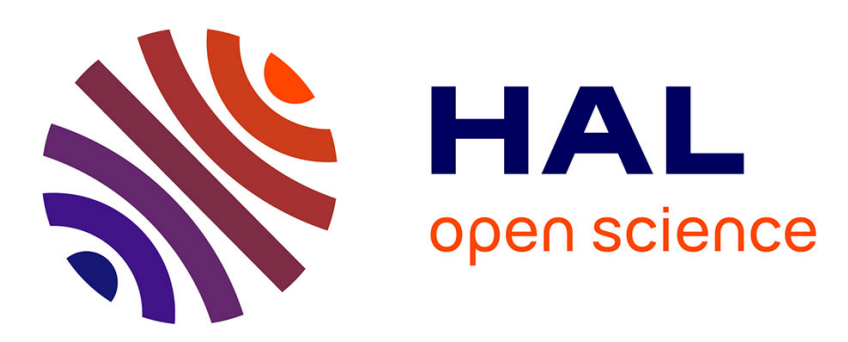

\title{
Hodgkin lymphoma in a sickle cell anaemia child treated with hydroxyurea
}

\author{
L. Couronné, P. Schneider, M. Montalembert, C. Dumesnil, A. Lahary, J. P. \\ Vannier
}

\section{To cite this version:}

L. Couronné, P. Schneider, M. Montalembert, C. Dumesnil, A. Lahary, et al.. Hodgkin lymphoma in a sickle cell anaemia child treated with hydroxyurea. Annals of Hematology, 2008, 88 (6), pp.597-598. 10.1007/s00277-008-0632-3 . hal-00486536

\section{HAL Id: hal-00486536 https://hal.science/hal-00486536}

Submitted on 26 May 2010

HAL is a multi-disciplinary open access archive for the deposit and dissemination of scientific research documents, whether they are published or not. The documents may come from teaching and research institutions in France or abroad, or from public or private research centers.
L'archive ouverte pluridisciplinaire HAL, est destinée au dépôt et à la diffusion de documents scientifiques de niveau recherche, publiés ou non, émanant des établissements d'enseignement et de recherche français ou étrangers, des laboratoires publics ou privés. 


\title{
Hodgkin lymphoma in a sickle cell anaemia child treated with hydroxyurea
}

\author{
L. Couronné • P. Schneider • M. de Montalembert • \\ C. Dumesnil • A. Lahary • J. P. Vannier
}

Received: 17 June 2008 / Accepted: 13 October 2008 / Published online: 1 November 2008

(C) Springer-Verlag 2008

\section{Dear Editor,}

Hydroxyurea (HU) is a chemotherapeutic agent used in adults and children severely affected with sickle cell anaemia (SCA). Current indications are: recurrent painful crises, more than two acute chest syndromes, early chronic organ damage (respiratory, renal, hepatic, myocardial insufficiencies), association with an auto-immune disease or Hb level below $6 \mathrm{~g} / \mathrm{dL}[4,5]$.

$\mathrm{HU}$ is the only drug that has been proven to modify the disease at short- or middle-term with an acceptable shortterm toxicity [1]. However, few data are available about the potential risk of carcinogenesis. We report the case of a Hodgkin lymphoma that occurred after 4 years of $\mathrm{HU}$ therapy.

Our patient was diagnosed at the age of 12 months as compound heterozygote for $\mathrm{HbS}$ and $\beta^{0}$-thalassaemia. When he was 13 years old, he presented pulmonary arterial hypertension leading to prescribe nocturnal oxygen therapy. At the same time, our patient developed severe anaemia $(6.0 \mathrm{~g} / \mathrm{dL} \mathrm{Hb})$, thrombocytosis $\left(706.10^{9} / \mathrm{L}\right.$ platelets $)$ and hyperleukocytosis $\left(28.10^{9} / \mathrm{L}\right.$ white blood cells).

At the age of 14 years and given the cardiovascular and haematological consequences of the disease, HU therapy

L. Couronné • P. Schneider · C. Dumesnil • J. P. Vannier $(\bowtie)$

Pediatric Hematology and Oncology, Hospital Charles Nicolle,

1 , rue de Germont,

76000 Rouen, France

e-mail: jean-pierre.vannier@chu-rouen.fr

M. de Montalembert

Pediatrics Unit, Hospital Necker,

Paris, France

A. Lahary

Department of Biochemistry, Hospital Charles Nicolle,

Rouen, France was started at an initial dose of $17 \mathrm{mg} / \mathrm{kg}$ daily. Six months after the initiation of $\mathrm{HU}$, all the haematological parameters improved, and 1 year later, pulmonary pressure decreased allowing a reduction of oxygen therapy.

Four years after the initiation of HU treatment, our patient presented a Hodgkin lymphoma stage IIAa. He was enrolled in MDH 03 protocol (running French protocol) and received so far four courses of vinblastine, bleomycin, etoposide and prednisone (VBVP). He is currently in complete remission and a 20-Gy involved fields radiotherapy is planned.

Only few reports of malignancies appeared during HU therapy have been published. Among 225 children with SCA, one case of acute lymphoblastic leukaemia occurred in a girl treated for 1.5 months with hydroxyurea [6]. Moschovi et al. reported a SCA boy who developed Hodgkin lymphoma 6 months after HU treatment [7]. Three other single reports described haematological cases (acute myeloblastic leukaemia) occurring after 6 years [9] and, in two cases, 8 years of therapy [2]. In Schultz' study, three SCA patients with cancer had been exposed to HU including a 14-year-old boy with acute lymphoblastic leukaemia diagnosed 3 months after initiating therapy, a 39-year-old man with fatal testicular seminoma and a 47year-old woman with two types of breast cancer and malignant histiocytosis [8]. With the present report, nine malignancies have been so far reported.

In vitro, DNA damage cannot be fully repaired in the presence of $\mathrm{HU}$, leading to the accumulation of somatic mutations and chromosomal damages. In contrast, using a VDJ assay, no study shows a significant increased number of VDJ mutations in SCA children with long HU exposure [3, 10].

It is impossible to affirm a causative association between $\mathrm{HU}$ and cancers, but it is important to record all the cases. The indications for HU treatment must remain cautious. 
The safety of long-term administration, particularly with respect to leukaemogenesis, should now be evaluated in a long-term follow-up of cohorts of children.

\section{References}

1. Charache S, Terrin ML, Moore RD, Dover GJ, Barton FB, Eckert SV, McMahon RP, Bonds DR (1995) Effect of hydroxyurea on the frequency of painful crises in sickle cell anemia. Investigators of the Multicenter Study of Hydroxyurea in Sickle Cell Anemia. N Engl J Med 332:1317-1322 doi:10.1056/NEJM199505183322001

2. Ferster A, Sariban E, Meuleman N, Belgian Registry of Sickle Cell Disease patients treated with Hydroxyurea (2003) Malignancies in sickle cell disease patients treated with hydroxyurea. Br J Haematol 123:368-369 doi:10.1046/j.1365-2141.2003.04614.x

3. Hanft VN, Fruchtman SR, Pickens CV, Rosse WF, Howard TA, Ware RE (2000) Acquired DNA mutations associated with in vivo hydroxyurea exposure. Blood 95:3589-3593

4. Haute autorité de Santé. Recommandations pour la pratique clinique. Prise en charge de la drépanocytose chez l'enfant et l'adolescent. Septembre 2005. Available at http://www.has-sante. fr/portail/upload/docs/application/pdf/Drepanocytose_reco.pdf

5. de Montalembert M (2004) Management of sickle cell disease. Rev Prat 54:1557-1564

6. de Montalembert M, Brousse V, Elie C, Bernaudin F, Shi J, Landais P, French Study Group on Sickle Cell Disease (2006) Long-term hydroxyurea treatment in children with sickle cell disease: tolerance and clinical outcomes. Haematologica 91:125128

7. Moschovi M, Psychou F, Menegas D, Tsangaris GT, TzortzatouStathopoulou F, Nikolaidou P (2001) Hodgkin's disease in a child with sickle cell disease treated with hydroxyurea. Pediatr Hematol Oncol 18:371-376 doi:10.1080/088800101316921985

8. Schultz WH, Ware RE (2003) Malignancy in patients with sickle cell disease. Am J Hematol 74:249-253 doi:10.1002/ ajh. 10427

9. Wilson S (2000) Acute leukemia in a patient with sickle-cell anemia treated with hydroxyurea. Ann Intern Med 133:925-926

10. Zimmerman SA, Schultz WH, Davis JS, Pickens CV, Mortier NA, Howard TA, Ware RE (2004) Sustained long-term hematologic efficacy of hydroxyurea at maximum tolerated dose in children with sickle cell disease. Blood 103:2039-2045 doi:10.1182/blood2003-07-2475 